\title{
Physico-chemical changes in "Xiem" banana cultivar (cultivated in Vietnam) during ripening and storage at different temperatures
}

\author{
${ }^{1}$ Thuy, N.M., ${ }^{1}$ Linh, M.N., ${ }^{1}$ My, L.T.D., ${ }^{2}$ Minh, V.Q. and ${ }^{1}$ Tai, N.V. \\ ${ }^{1}$ College of Agriculture, Can Tho University, Can Tho city, Can Tho, Vietnam \\ ${ }^{2}$ College of Environment and Natural Resources, Can Tho University, Can Tho, Vietnam
}

\section{Article history:}

Received: 1 June 2021

Received in revised form: 2

July 2021

Accepted: 27 September 2021

Available Online: 19

December 2021

\section{Keywords:}

"Xiem" banana cultivar,

Physical and chemical

properties,

Ripening,

Colour chart,

Correlation

\section{DOI:}

https://doi.org/10.26656/fr.2017.5(6).370

\begin{abstract}
There are changes in chemical and physical characteristics involved in the ripening of bananas. This study evaluated the changes in physico-chemical and nutritional characteristics of the "Xiêm" banana cultivar at the harvesting (unripe fruit) and ripe stages (ripe fruit). As the pulp to peel ratio and titrable acidity increased, the firmness decreased with an increase in ripening time. A significant increase in total polyphenol content and decrease in beta-carotene and vitamin $\mathrm{C}$ content was observed at climacteric peak during ripening. During ripening, the banana peel colour changed from green to yellow, the pulp softened, the flavour develops, and the moisture is lost. "Xiem" banana variety was fully mature after 7 and 22 days of storage at $28-30^{\circ} \mathrm{C}$ and $13-15^{\circ} \mathrm{C}$, respectively. The correlation between various stages of ripeness and these properties were determined and the correlation coefficients were calculated. A very high coefficient of determination $\left(r^{2}>0.937\right)$ was recorded between physical properties (pulp firmness/peel colour) and chemical properties (starch/sugar) of banana fruit with the stage of ripeness.
\end{abstract}

\section{Introduction}

Vietnam is blessed with large areas appropriate for banana growing. Large-scale cultivation of bananas for fresh fruit consumption. There are many banana cultivars, in which the "Xiem" cultivar is the most popular in Vietnam. The banana fruit has minerals, vitamins, sugars that are beneficial in maintaining an ideal weight and balanced nutrition. Bananas are also a good source of different types of fibre, such as pectin. Some of the pectin in bananas are water-soluble (Duan et al., 2008).

The "Xiem" bananas are harvested at a specific maturity stage based on the age of the bunch, the interval between flowering and harvesting and the colour of the peel and pulp. Quality is an important factor in the banana market, especially when freshly consumed. Banana in the domestic market is harvested at the maturity stage (unripe fruit) which is important in the quality of bananas. The small difference in the maturity of bananas after harvesting makes a large difference in eating quality and consequently consumer satisfaction.

The ripening of bananas includes both chemicals as well as physical changes. As a banana ripens, in relation to physical properties, the change in the texture of the banana was very obvious as some parts soften while others are destroyed with the formation of new parts. The chemical changes involved the formation of simpler sugars from the complex carbohydrates that constitute raw bananas and the formation of new chemicals that result in the change in colour and taste. When the proportion of water-soluble pectin increases, it results in the soft texture of the bananas as they age. Banana is also a good source of vitamin $\mathrm{C}$, has minimal fat and sodium with cholesterol, is delicious, healthy and nutritious when eaten raw or used in cooking. Similarly, the antioxidants gallocatechin, catechin, and epicatechin were also identified in bananas (Someya et al., 2002). Fruit sugars continue to increase through to senescence, these changes in the acid and sugar content during ripening, results in ripe bananas that are sweeter and lightly sour.

However, research on the evaluation of bananas at the ripening stage during storage in Vietnam is still limited. Thus, the purpose of this experiment was to study the influence of storage conditions and the degree of ripening on physico-chemical attributes (colour, L*, $a^{*}, b^{*}$, total soluble solids, titratable acidity, fibre, moisture content, sugars) of banana fruit. The colour chart of bananas at various stages after harvesting has been established. 
The most important attributes of the fruits, according to the consumer preferences at purchasing banana, are the flavour, shelf life and appearance (length, diameter and colour) (Matsuura et al., 2004). Researches describing the physical and chemical properties of different banana cultivars are available in the scientific literature (Gomes and Prado, 2007), however, these studies usually evaluate the pulp of some cultivars only from ripe fruits, not characterizing unripe pulp and peel, which is important due to the high starch content and other antioxidant compounds present in these parts of the unripe fruits that are components of the human diet (Borges et al., 2014).

The characterization of the banana is also useful information for its commercial quality. Therefore, the study on physical and chemical parameters related to its fruit quality and seeking to maintain the desirable characteristics required by market standards was very important. In this context, the objective of this work was to assess the physical and chemical characteristics of fruits at two maturation stages, unripened and ripened. The relationship between the various physico-chemical properties of banana ripened at ambient $\left(28-30^{\circ} \mathrm{C}\right)$ and low temperature $\left(13-15^{\circ} \mathrm{C}\right)$, as a predictive tool for ripening quality and usage was established.

\section{Materials and methods}

\subsection{Materials}

Banana (Musa spp.) bunches were collected from $\mathrm{Ca}$ Mau province, Viet Nam when the fruits were still green but have reached maturity (Figure 1). The fruits were washed in running water and left on an absorbent paper for the latex to coagulate. Then, banana fruits were packed in plastic bags and kept at different temperatures $\left(13-15^{\circ} \mathrm{C}\right.$ and $\left.28-30^{\circ} \mathrm{C}\right)$ until it has achieved stage-7 colour (from all green to all yellow). About $15 \mathrm{~kg}$ of raw material was collected for each survey, the maturity of the fruit is determined by physical properties (weight, volume, firmness, colour, diameter) and chemical properties (starch, sugar, $\beta$-carotene, total polyphenol content, titratable acidity and minerals).

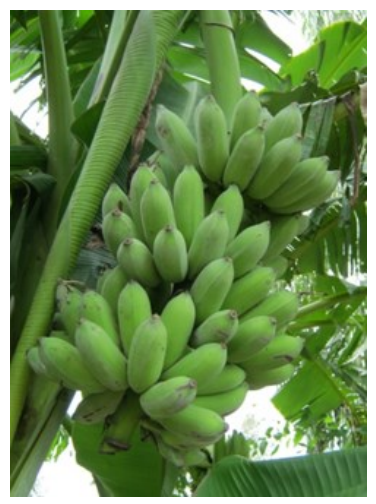

Figure 1. The bananas bunch is ready for harvest

\subsection{Physical characteristics}

\subsubsection{Weight of the fruit}

The weight $(\mathrm{g})$ of the fruit was measured by using a digital balance with a sensitivity of $\pm 0.01 \mathrm{~g}$.

\subsubsection{Fruit length, diameter, peel thickness}

The fruit length (L), diameter (D) and peel thickness (mm) were measured in the median area of each fruit, perpendicular to its larger axis, with a digital calliper (accuracy of $0.01 \mathrm{~mm}$ ).

\subsubsection{Volume of fruit}

The volume $(\mathrm{V})$ of the fruit was defined as the ratio of the mass of a sample to the solid volume accordingly occupied was determined by the liquid displacement method. The amount of displaced water was recorded from the graduated scale of the measuring cylinder (Akbolat et al., 2008).

\subsubsection{Bulk density}

The bulk density is the ratio of the mass of fruit to its total volume and was determined with a weight per hectoliter tester, which was calibrated in $\mathrm{kg} . \mathrm{m}^{-3}$.

\subsubsection{Surface area}

The surface area was measured by the peeling method

\subsubsection{Pulp firmness}

The firmness of banana pulp was measured using a PenetrometerEY-30 Fruit Firmness, with a tip diameter of $7.9 \mathrm{~mm}$ (China)

\subsubsection{Ratio of pulp and peel}

The pulp-to-peel ratio was obtained by dividing the pulp weight by the peel weight using formula 1 .

$$
\text { Pulp to peel ratio }=\frac{\text { Weight of pulp }}{\text { Weight of peel }}
$$

\subsubsection{Peel colour}

The colour of banana peel was measured by using Colorimeter (Japan), five replicates were taken. $L^{*}, a^{*}$ and $\mathrm{b}^{*}$ values were recorded and these values were used to calculate Chroma (C) (equation 2).

$$
C=\sqrt{\left(a^{*}\right)^{2}+\left(b^{*}\right)^{2}}
$$

\subsubsection{Hue angle $(H)$ value}

It is the angle between the $a^{*}$ and $b^{*}$ axes (equation 3 ), indicating the colour saturation of the subject.

$$
H=\tan ^{-1}\left(\frac{b^{*}}{a^{*}}\right)
$$


Chroma and Hue angles were used for describing visual colour appearance (Bernalte et al., 2003).

\subsubsection{Weight loss}

Initially, around $200 \mathrm{~g}$ of fruit (in transparent plastic boxes) was weighed with HL Electronic Balance, with an accuracy of $0.001 \mathrm{~g}$. Fruits were stored for 8 and 22 days at ambient temperatures $\left(28 \pm 2^{\circ} \mathrm{C}\right)$ and low temperatures $\left(12 \pm 1^{\circ} \mathrm{C}\right)$, respectively, they were weighed every 2 days. The results were converted into percentages with equation 4 .

$\% W L=\frac{W_{i}-W_{f}}{W_{i}} \times 100$

Where $\% W L$ is percentage weight loss, $\mathrm{W}_{i}$ is initial fruit weight in $\mathrm{g}, \mathrm{W}_{f}$ is final fruit weight in $\mathrm{g}$ at the indicated time.

\subsection{Determination of chemical characteristics}

\subsubsection{Titratable acidity}

The acid content was determined as \% malic acid present in bananas by the method given by the standard AOAC (1980).

\subsubsection{Soluble solids content}

It was evaluated with a portable digital refractometer (Atago model N1), with readings in the range of 0 to $32^{\circ}$ Brix.

\subsubsection{Carbohydrate content}

The content of carbohydrates was determined according to the method of McCseady (1971) and Dubois et al. (1956).

\subsubsection{The $\beta$-carotene content}

The content of carotenes expressed as $\beta$-carotene was calculated using equation 5 , according to the method of Fikselová et al. (2008).

$\beta$ - carotene $(\mu \mathrm{g} / \mathrm{g})=\frac{A \times d \times V}{E_{1 c m}^{10} \times w}$

Where $A$ is absorbance, $\mathrm{d}$ is dilution $(\mathrm{g} / \mathrm{mL}), E_{1 \mathrm{~cm}}^{1 \%}$ is absorption coefficient of $\beta$-carotene in petroleum ether (2592), $w$ is the weight of the sample ( $\mathrm{g}$ ) and $V$ is the total volume of extract $(\mathrm{mL})$. Multiplied by 100 to give the carotene content in $\mu \mathrm{g} / 100 \mathrm{~g}$.

\subsubsection{The vitamin $C$ content}

The content of vitamin $\mathrm{C}$ was determined by the titration method with iodine using equation 6 (Tran et al., 2004).

Vitamin C $(m g \%)=\frac{(a-b) \times 0.088 \times 100}{10} \times \frac{100}{m}$

Where $a$ is the volume of $0.001 \mathrm{~N} \mathrm{KIO}_{3} / \mathrm{KI}$ solution used for vitamin $\mathrm{C}$ extract $(\mathrm{mL}), b$ is the volume of 0.001
$\mathrm{N} \mathrm{KIO}_{3} / \mathrm{KI}$ solution used for the control sample, 100 is the volume of the volumetric flask $(\mathrm{mL}), 0.088$ is the weight of ascorbic acid corresponds to $1 \mathrm{~mL}$ of $0.001 \mathrm{~N}$ $\mathrm{KIO}_{3} / \mathrm{KI}$ solution $(\mathrm{mg})$, and $m$ is the weight of the sample (g).

\subsubsection{The content of calcium and potassium}

The determination of calcium and potassium was carried out by flame photometry, following the procedure of Arunkumar et al. (2015), using an FP6410 Flame Photometer.

\subsubsection{Total calories}

The total calories of the fruit were calculated by the formula as follows: total calories $(\mathrm{kcal})=$ fat $(\mathrm{g}) \times 9$ $(\mathrm{kcal} / \mathrm{g})+$ protein $(\mathrm{g}) \times 4(\mathrm{kcal} / \mathrm{g})+$ total carbohydrate $(\mathrm{g}) \times 4(\mathrm{kcal} / \mathrm{g})($ Thompson and Manore, 2017).

\subsubsection{The total polyphenols content}

The total polyphenols content was determined by the Folin-Ciocalteu (Olsson et al., 2006). The results were expressed in milligrams of gallic acid equivalent $/ 100 \mathrm{~g}$ of sample.

\subsection{Statistical analysis}

Data analyses were carried out using STATGRAPHICS Centurion XV (USA). Values were expressed as mean \pm SD. The significance/nonsignificance of results was determined using one-way ANOVA and Duncan test.

\section{Results and discussion}

\subsection{Physical properties of banana}

Some physical properties of banana fruit ("Xiem" cultivar) were determined as displayed in Table 1. These properties are very important for designing agricultural machinery. Usually, the peel colour is used as a predictor of shelf-life for retail distribution which changes from green to yellow during ripening. There is a significant change in $L^{*}, a^{*}$ and $b^{*}$ value of unripe and ripe bananas. Bananas showed a significant increase in their $\mathrm{L}^{*}$ and $\mathrm{b}^{*}$ values as the fruit ripened $(71.77 \pm 1.39$ and $57.56 \pm 0.69$, respectively). The low $a^{*}$ value was recorded in bananas at the unripe stage with a negative value. The chroma and hue colour space values of the fruits were significantly affected by the ripening stages. "Xiêm" banana cultivar gave significantly increased chroma values as the fruit ripens. The observed metric chroma (C) of unripe banana and ripe banana were $36.20 \pm 0.42$ and $57.62 \pm 0.75$ and the hue angle $\left(\mathrm{H}_{\mathrm{o}}\right)$ of banana at the initial and the end of the storage period were in the range of $-64.72 \pm 1.17$ and $87.32 \pm 0.23$, respectively. 
Table 1. Physical properties of banana fruit

\begin{tabular}{cccc}
\hline Physical properties & Number of replications & Unripe banana & Ripe banana \\
\hline Length $(\mathrm{mm})$ & 10 & $118.63 \pm 1.14$ & $114.87 \pm 3.80$ \\
Diameter $(\mathrm{mm})$ & 10 & $39.88 \pm 0.21$ & $38.51 \pm 1.27$ \\
Surface area $\left(\mathrm{cm}^{2}\right)$ & 10 & $113.92 \pm 2.62$ & $110.73 \pm 4.68$ \\
Mass of fruit $(\mathrm{g})$ & 10 & $111.08 \pm 3.23$ & $104.76 \pm 6.58$ \\
Fruit volume $\left(\mathrm{cm}^{3}\right)$ & 10 & $108.67 \pm 1.53$ & $102.33 \pm 3.21$ \\
Fruit density $\left({\left.\mathrm{kg} . \mathrm{m}^{-3}\right)}^{3}\right.$ & 10 & $1.02 \pm 0.02$ & $1.02 \pm 0.03$ \\
Fruit hardness $(\mathrm{g} \mathrm{force})$ & 10 & $579.50 \pm 12.61$ & $49.00 \pm 5.16$ \\
$\mathrm{~L}^{*}$ & 5 & $57.08 \pm 1.66$ & $71.77 \pm 1.39$ \\
$\mathrm{a}^{*}$ & 5 & $-15.46 \pm 0.74$ & $2.66 \pm 0.04$ \\
$\mathrm{~b}^{*}$ & 5 & $32.73 \pm 0.42$ & $57.56 \pm 0.69$ \\
$\mathrm{C}$ & 5 & $36.20 \pm 0.42$ & $57.62 \pm 0.75$ \\
$\mathrm{H}_{\mathrm{o}}$ & 5 & $-64.72 \pm 1.17$ & $87.32 \pm 0.23$ \\
Mass of peel $(\mathrm{g})$ & 5 & $29.96 \pm 1.03$ & $27.11 \pm 1.70$ \\
Ratio of pulp/peel & 5 & $2.71 \pm 0.21$ & $2.86 \pm 0.11$ \\
\hline
\end{tabular}

Values are expressed as the mean \pm standard deviation. $L^{*}$ : lightness, $a^{*}$ : the red/green opponent colours, with green at negative $a^{*}$ values and red at positive $a^{*}$ values. $b^{*}$ : the yellow/blue opponent colours, with blue at negative $b^{*}$ values and yellow at positive $b^{*}$ values.

The weight of peel decreased with the increase of storage time as the fruit ripens, corresponding with the pulp to peel ratio ranging from 2.71 for stage 1 (unripe) to 2.86 for stage 7 ripening. Patil and Shanmugasundaram (2015) recorded a similar trend in the pulp to peel ratio of Monthan bananas ranging from 2.5 to 5.95 for stage 1 and 9 ripening, respectively. The slight variations in the values obtained may be due to differences in peel morphology and variations in the atmospheric storage conditions. The water content of the peel reduces by transpiration, this explains the weight loss of the peel as ripening progress. It may be due to the collapse of the cell wall leading to the creation of air spaces in the middle lamella and this causes the thinning of the peel. The physical characteristics analysis of the fruit also showed no significant difference in length, diameter, volume, density, mass, surface area for unripe (stage 1) and ripe bananas (stage 7). However, the textural properties of bananas declined while their colour increased with the ripening period.

\subsection{Colour chart of "Xiem" banana variety}

In the trade market, the ripening stages of bananas are usually discerned. The banana fruits were stored for 7 and 22 days at $28-30^{\circ} \mathrm{C}$ and $13-15^{\circ} \mathrm{C}$, respectively. Under both temperatures, the banana fruit matures and attains a yellow colour. The percentage of its yellow colour gradually appears on the peel at different levels over time during storage. The colour chart of banana fruits in various stages is illustrated in Figures 2 and 3. The peel colour changes from green to yellow (seven days) at different temperatures due to the synthesis of a few pigments (Yang et al., 2011). The banana fruit is still useful at the onset of senescence (Day 8 and Day 22 at

$28-30^{\circ} \mathrm{C}$ and $13-15^{\circ} \mathrm{C}$, respectively) for the preparation of products such as cake, wine and vinegar in order to reduce post-harvest losses significantly.

Chilling injury symptoms vary depending on the
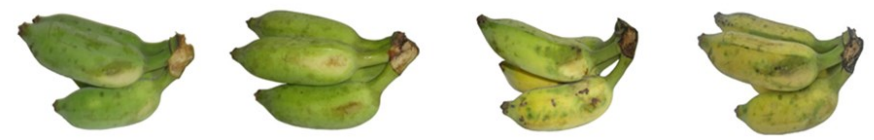

Day 0. All Green

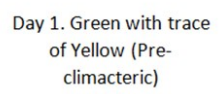

Day 2. More Green Day 3. Half Green/Half
Yellow (Climacteric) climacteric) Yellow) (Onset of climacteric)
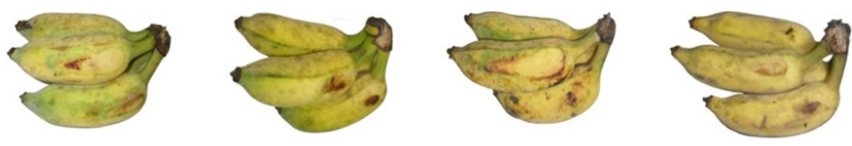

Day 4.More Yellow (>70\%) than Green (Climacteric)

Day 5. Yellow with Green Tips and Green Necks (>90\%Yellow)

Day 6. Almost Yellow (95\% Yellow) (Climacteric)

Day 7. All Yellow (Climacteric)

Figure 2. Banana colour chart at ambient temperature storage $\left(28-30^{\circ} \mathrm{C}\right)$
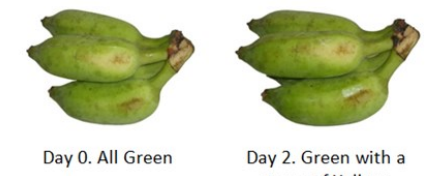
trace of Yellow
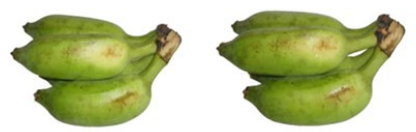

Day 4. More Green than Yellow $(\approx 7 \%$

Day 6. More Green than

Day 0. All Green
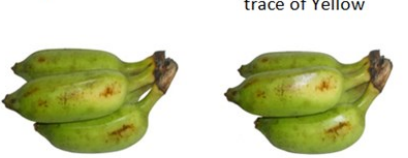

Day 8. More Green than Yellow ( $\approx 15 \%$ Yellow)

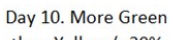
than Yellow $(\approx 20 \%$
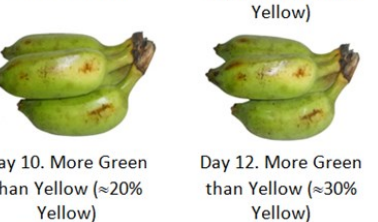

Day 12. More Green than Yellow $(\approx 30 \%$

$$
\text { Yellow) }
$$

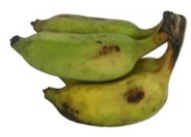

Day 16. More Yellow ( $\approx 70 \%$ Yellow) than

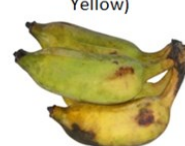

Day 18. More Yellow $(\approx 85 \%)$ than Green

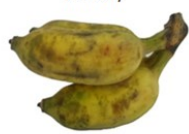

Day 20. More Yellow $(\approx 90 \%)$ than Green

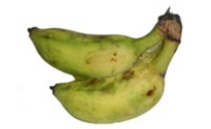

Day 14. Half Green - Half Yellow

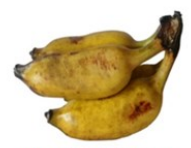

Day 22. All Yellow Green

Figure 3. Banana colour chart at low temperature storage (13$\left.15^{\circ} \mathrm{C}\right)$ 
banana cultivar and appear to be related to a genomic group (Lichtemberg et al., 2001). A temperature of $13^{\circ} \mathrm{C}$ is effective in delaying the ripening of bananas (cultivar Nanicão) stored for 17 days (Fernandes et al., 2010). Bananas (cultivar Prata-Anã) stored for 35 days at temperatures of 10 to $12^{\circ} \mathrm{C}$ showed no symptoms of chilling injury (Martins et al., 2007). A maximum cold storage period at $14^{\circ} \mathrm{C}$ was recommended for 'BRS Caipira' of 21 days (Lima et al., 2014). Low-temperature storage possibly affected starch to sugar conversion with the accumulation of soluble solids in banana fruits. These results support the necessity to limit the time for low-temperature storage of the "Xiem" banana variety growing in Vietnam to offer better quality banana fruits to the consumers.

\subsection{Some chemical characteristics of banana fruit}

As indicated in Table 2, one serving of ripe banana (100 g), provides about $23.79 \mathrm{~g}$ carbohydrate, $12.96 \mathrm{~g}$ sugar (naturally occurring), $1.09 \mathrm{~g}$ protein, $0.38 \mathrm{~g}$ fat, $376.14 \mathrm{mg}$ potassium, $2.18 \mathrm{~g}$ fibre and 94.22 calories.

\subsubsection{Moisture content}

The selected samples of bananas had a moisture content of $73.10 \pm 0.82$ and $72.82 \pm 1.24 \mathrm{~g} / 100 \mathrm{~g}$ for unripe and ripe bananas, respectively.

\subsubsection{Carbohydrates}

Bananas were a rich source of carbohydrates $(23.79 \pm 0.40$ to $24.61 \pm 0.20 \mathrm{~g} / 100 \mathrm{~g})$, which occurs mainly as starch in unripe bananas and sugars in ripe bananas. The main component of unripe bananas was starch $(22.12 \pm 0.15 \mathrm{~g} / 100 \mathrm{~g})$, they had less sugar, which can be especially beneficial to diabetic people. Bananas have a relatively low glycemic index (GI) of 48-54 (Harvard Health Publishing, 2020), depending on their ripeness. Bananas contain high resistant starch and fibre, which could explain their low GI (Hettiaratchi et al., 2011). During ripening, the starch is converted into sugars when the banana is fully ripened. In ripe bananas, the total sugar content could reach $13 \%$ of the fresh weight. Although the acid content still tends to increase when the fruit is fully ripe, the high sugar content that is converted from starch also makes the fruit sweeter (sugar/acid ratio). High content of simple sugars in bananas was found in the study of Segundo et al. (2017). The yellow banana with brown spots has more sugar and less fibre than a green banana of the same size. The fibre content of unripe and ripe banana pulp were 2.23 and $2.18 \mathrm{~g} / 100 \mathrm{~g}$, respectively.

\subsubsection{Acid}

It was observed that the titratable acidity of bananas continuously increases after harvest and as the banana ripens. The initial titrable acidity was found to be $0.16 \%$ (green banana) and increased throughout its ripening time $(0.27 \%$ in a ripe banana). These results were in agreement with a previous study, which reported that the concentration of malic acid and citric acid increased until the ripe stage was reached (Chandra et al., 2020). Adi et al. (2019) also reported that the acidity of the plantain fruit increased from stage $1(0.06 \%)$ to stage $7(0.29 \%)$ where it peaked. According to Von Loesecke (1950), titratable acidity of the pulp increased to a peak during ripening in the case of some varieties.

\subsection{4 $\beta$-carotene, vitamin $C$ and total polyphenol}

The content of $\beta$-carotene in the unripe pulp of the

Table 2. Some chemical characteristics (per $100 \mathrm{~g}$ ) of banana fruit

\begin{tabular}{lccc}
\hline \multicolumn{1}{c}{ Parameters } & Number of replications & Unripe banana & Fully ripe banana \\
\hline Moisture content $(\mathrm{g})$ & 5 & $73.10 \pm 0.82$ & $72.82 \pm 1.24$ \\
Total carbohydrate $(\mathrm{g})$ & 5 & $24.61 \pm 0.20$ & $23.79 \pm 0.40$ \\
Starch $(\mathrm{g})$ & & $22.12 \pm 0.15$ & $1.58 \pm 0.10$ \\
Sugar $(\mathrm{g})$ & 5 & 0 & $12.96 \pm 0.74$ \\
Titratable acidity $(\mathrm{g})$ & 5 & $0.16 \pm 0.01$ & $0.27 \pm 0.02$ \\
Sugar/acid ratio & 5 & - & 44.69 \\
Protein $(\mathrm{g})$ & 5 & $1.08 \pm 0.01$ & $1.09 \pm 0.01$ \\
Lipid $(\mathrm{g})$ & 5 & $0.30 \pm 0.05$ & $0.38 \pm 0.02$ \\
B-carotene content $(\mu \mathrm{g} / \mathrm{g})$ & 5 & $343.28 \pm 1.77$ & $294.87 \pm 2.35$ \\
Vitamin C content $(\mathrm{mg})$ & 5 & $10.30 \pm 0.58$ & $8.70 \pm 0.04$ \\
Total polyphenol (mg GAE) & 5 & $23.60 \pm 1.53$ & $73.13 \pm 1.30$ \\
Calcium (mg) & 5 & $7.08 \pm 0.35$ & $6.88 \pm 0.22$ \\
Potassium (mg) & 5 & $368.87 \pm 3.26$ & $376.14 \pm 2.89$ \\
Sodium (mg) & 5 & $1.17 \pm 0.02$ & $1.22 \pm 0.05$ \\
Fibre (g) & 5 & $2.23 \pm 0.20$ & $2.18 \pm 0.27$ \\
Total calories $(\mathrm{kcal})$ & - & 96.54 & 94.22 \\
\hline
\end{tabular}

Values are expressed as the mean \pm standard deviation. 
"Xiem" banana variety was higher $(343.28 \pm 1.77 \mathrm{mg} / 100$ g), differing from the content of the ripe pulp $(294.87 \pm 2.35 \mathrm{mg} / 100 \mathrm{~g})$. Analysis of three cultivars grouped in Thailand, Malaysia and Micronesia found similar levels $(345,411$, and $420 \mu \mathrm{g}$ of $\beta$-carotene equivalents/100 g) (Siong, 1985; Englberger, Wills, Blades et al., 2006; Puwastien et al., 2020). These results also concurred with Newilah et al. (2009) who reported that the principal carotenoids were $\beta$-carotene, $\alpha$ carotene and lutein, the first two nutrients being the major banana and plantain carotenoids. The decreased concentrations of these carotenoids during ripening may be due to their degradation or to the synthesis of other carotenoids such as lutein (Newilah et al., 2009). Aquino et al. (2018) reported that the reduction of 7.3 and $8.5 \%$ in the mean $\alpha$-carotene and $\beta$-carotene concentrations in the ripe pulp, respectively, was due to fruit ripening. Lutein concentration hardly changed due to fruit ripening. However, this decrease did not occur in all the bananas, according to some studies, soil fertilization, which was applied in the experiment during the fruit production cycle, could be one of the factors that affected carotenoid biosynthesis in fruits (Gross, 1987). There are 149 local cultivars of edible bananas in Southeast Asia (Valmayor et al., 2002), and some have an average concentration of $\beta$-carotene that ranges from 230 to $1370 \mu \mathrm{g} / 100 \mathrm{~g}$ DW (Englberger et al., 2003; Englberger, Wills, Blades et al., 2006; Englberger, Schierle, Aalbersberg et al., 2006).

Bananas are also a good source of vitamin C. However, ripe bananas had lower concentrations of vitamin $\mathrm{C}(8.70 \pm 0.04 \mathrm{mg} / 100 \mathrm{~g})$ than unripe bananas $(10.30 \pm 0.58 \mathrm{mg} / 100 \mathrm{~g})$. Lee and Kader (2000) also found that the vitamin $\mathrm{C}$ content in bananas decreased with maturation and ripeness.

The total polyphenol compounds of unripe and ripe bananas have been identified, at $24.68 \pm 0.15$ and $68.43 \pm 0.25 \mathrm{mg} \mathrm{GAE} / 100 \mathrm{~g}$, respectively. These results were quite similar to the published results of Aquino et al. (2018). With fruit ripening, there was an increase in the content of phenolic compounds in the ripe pulp. Phenolics play a significant role in the prevention of many chronic diseases.

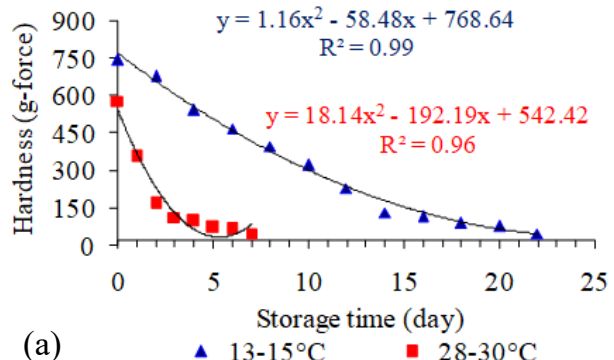

\subsubsection{Lipid and protein}

Bananas were low in fat and protein, with less than 0.38 and $1.09 \mathrm{~g}$ per $100 \mathrm{~g}$ ripe banana, respectively. These values mostly presented no significant difference between unripe and ripe bananas.

\subsubsection{Minerals}

The minerals content in banana fruits is primarily consistent with potassium (368.87 to $376.14 \mathrm{mg} / 100 \mathrm{~g}$, respectively for unripe and ripe bananas). Other minerals present are sodium (1.17 to $1.22 \mathrm{mg} / 100 \mathrm{~g})$ and calcium (4.8 to $5.1 \mathrm{mg} / \mathrm{g}$ ).

\subsection{Correlations between texture/yellow surface area and starch/sugar contents of banana fruit for during ripening}

For bananas, the texture is also an important part of their quality aspects. Texture perception is an important factor for the quality evaluation of fruit and vegetable products (Konopacka and Plocharski, 2004) and critical in determining the acceptability of fresh fruits (Sousa et al., 2007)

During maturation, banana fruit accumulates a large amount of starch, generally about $12-35 \%$ starch in fruit at commercial harvesting (Soares et al., 2011). As they ripen, starch decreases and soluble sugars may reach up to $20 \%$ (fresh weight) of the ripe pulp, in which $80 \%$ are sucrose and $20 \%$ are glucose and fructose (Shiga et al., 2011).

The changes in firmness, colour, starch and sugar from the pulp of the "Xiem" banana variety were identified at different ripening stages. It was observed that the firmness of banana fruit decreased significantly at ripening stage 4 (after 4 days of harvesting) and then gradually decreased, at the same time developing yellow coloured peel (Figure 4). Softening of "Xiem" bananas fruits seemed to be more closely related to starch levels. The yellow colour peel gradually increased during ripening and reached the highest value on days 7 and 22 , respectively at $28-30$ and $13-15^{\circ} \mathrm{C}$. It was observed that banana softening is a consequence of starch and cell wall degradation and transformation and the accumulation of soluble sugars in fruit (Figure 5).

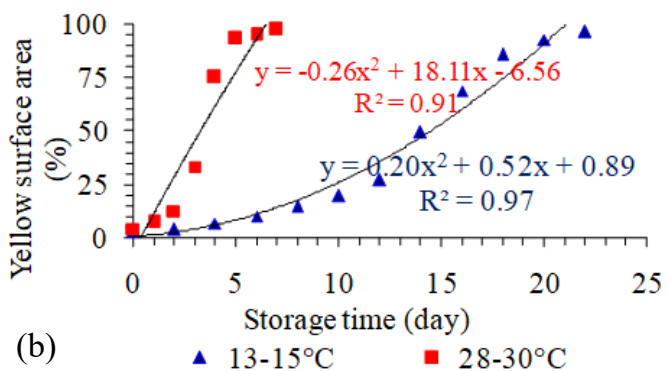

Figure 4. Changes in hardness (a) and yellow surface area (b) of banana fruits during ripening at different storage temperatures 
Ripening-associated changes in the amounts of starch, sugars and their contributions to fruit softening and yellow colour development in the "Xiem" banana variety were illustrated.

The polynomial regression analysis was used to describe the correlation between hardness/colour and starch/sucrose content of bananas changes with ripening (7 and 22 days at ambient and low temperature, respectively) (Figure 6 and Figure 7). Their best-fit equations (coefficient of determination, $\mathrm{r}^{2}$ ) for "Xiem" bananas variety were estimated.

\section{Conclusion}

In this study, the physical, chemical properties and nutrients of unripe and ripe banana fruit were evaluated. The colour chart of banana fruit at different ripeness levels and storage temperatures were established. The correlation of physical properties (texture, colour) and chemical properties (starch/sugar content) at ripening stages and coefficient of determination were found. At different levels of ripeness, the starch and sugar content correlated with the hardness and yellow surface areas. Therefore, these physical properties (hardness and yellow surface area) can be used to predict the starch/ sugar at different ripeness levels and storage temperatures. It is also a rapid predicting method of the maturity of banana fruit based on the obtained equations with high values of the coefficient of determination $\left(\mathrm{r}^{2}\right)$. The knowledge of the physicochemical and nutritional characteristics of banana fruits at each ripening stage allows for better selection depending on the industrial application.

\section{Conflict of interest}

The authors declare no conflict of interest.

\section{Acknowledgements}

The authors acknowledge the financial support to Can Tho University, Vietnam from the Research fund project code number T2020-67.

\section{References}

AOAC. (1980). Official methods of analyses. $13^{\text {th }}$ ed. Washington DC: Association of Official Analytical Chemists

Adi, D.D., Oduro, I.N. and Tortoe, C. (2019). Physicochemical changes in plantain during normal
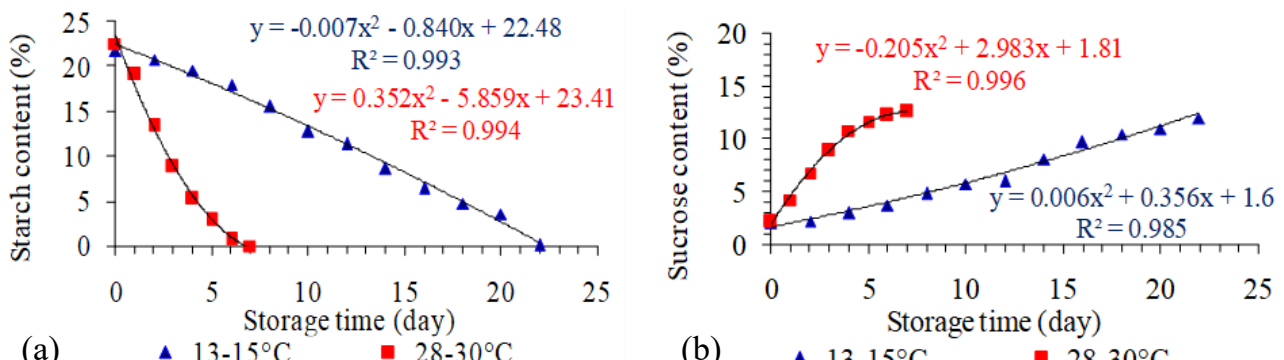

(b)

$\Delta 13-15^{\circ} \mathrm{C} \quad 28-30^{\circ} \mathrm{C}$

Figure 5. Changes in starch (a) and sucrose (b) content of banana fruits during ripening at different storage temperatures
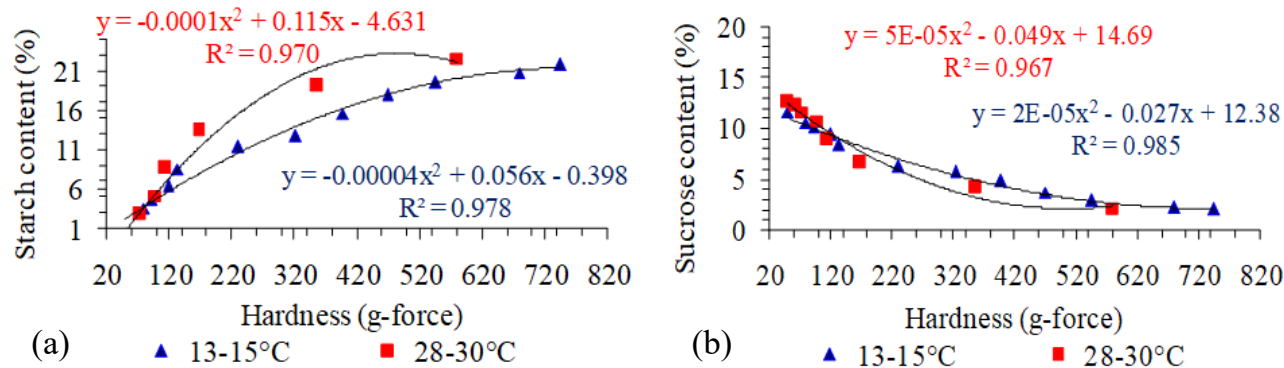

Figure 6. The relationship between hardness and starch (a)/sucrose (b) content of bananas during ripening at different storage temperatures
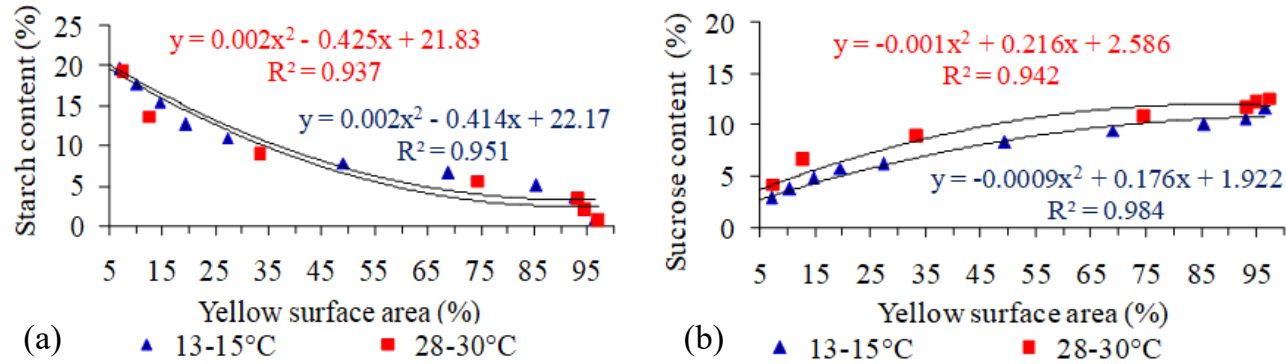

Figure 7. The relationship between yellow colour and starch (a)/sucrose (b) content of bananas during ripening at different storage temperatures 
storage ripening. Scientific African, 6, e00164. https://doi.org/10.1016/j.sciaf.2019.e00164

Akbolat, D., Ertekin, C., Menges, H.O., Ekinci, K. and Erdal, I. (2008). Physical and nutritional properties of jujube (Zizyphus jujuba Mill.) growing in Turkey. Asian Journal of Chemistry, 20(1), 757-766.

Aquino, C.F., Salomão, L.C.C., Pinheiro-Sant'ana, H.M., Ribeiro, S.M.R., Siqueira, D.L.D. and Cecon, P.R. (2018). Carotenoids in the pulp and peel of bananas from 15 cultivars in two ripening stages. Revista Ceres, 65(3), 217-226. https:// doi.org/10.1590/0034-737x201865030001

Arunkumar, D., Avinash, N.G., Rao, H., Robin, K.B. and Samshuddin, S. (2015). Estimation of calcium, potassium and sodium contents in commonly consumed food of Karnataka coastal belt region, India. Pelagia Research Library Der Chemica. Sinica, 6(4), 100-103.

Bernalte, M.J., Sabio, E., Hernandez, M.T. and Gervasini, C. (2003). Influence of storage delay on quality of 'Van'sweet cherry. Postharvest Biology and Technology, 28(2), 303-312. https:// doi.org/10.1016/S0925-5214(02)00194-1

Borges, C.V., de Oliveira Amorim, V.B., Ramlov, F., da Silva Ledo, C.A., Donato, M., Maraschin, M. and Amorim, E.P. (2014). Characterisation of metabolic profile of banana genotypes, aiming at biofortified Musa spp. cultivars. Food Chemistry, 145, 496-504. https://doi.org/10.1016/j.foodchem.2013.08.041

Chandra, R.D., Siswanti, C.A., Prihastyanti, M.N., Limantara, L. and Brotosudarmo, T.H. (2020). Evaluating Provitamin A Carotenoids and Polar Metabolite Compositions during the Ripening Stages of the Agung Semeru Banana (Musa paradisiaca L. AAB). International Journal of Food Science, 2020, 8503923. https://doi.org/10.1155/2020/8503923

Duan, X., Cheng, G., Yang, E., Yi, C., Ruenroengklin, N., Lu, W. and Jiang, Y. (2008). Modification of pectin polysaccharides during ripening of postharvest banana fruit. Food Chemistry, 111(1), 144-149.

j.foodchem.2008.03.049

Dubois, M., Gilles, K.A., Hamilton, J.K., Rebers, P.T. and Smith, F. (1956). Colorimetric method for determination of sugars and related substances. Analytical Chemistry, 28(3), 350-356. https://doi.org/10.1021/ac60111a017

Englberger, L., Darnton-Hill, I., Coyne, T., Fitzgerald, M.H. and Marks, G.C. (2003). Carotenoid-rich bananas: a potential food source for alleviating vitamin A deficiency. Food and Nutrition Bulletin, 24(4), 303-318. https:// doi.org/10.1177/156482650302400401
Englberger, L., Wills, R.B., Blades, B., Dufficy, L., Daniells, J.W. and Coyne, T. (2006). Carotenoid content and flesh color of selected banana cultivars growing in Australia. Food and Nutrition Bulletin, 27(4), 281-291. https:// doi.org/10.1177/156482650602700401

Englberger, L., Schierle, J., Aalbersberg, W., Hofmann, P., Humphries, J., Huang, A., Lorens, A., Levendusky, A., Daniells, J., Marks, G.C., Maureen, H. and Fitzgerald, M.H. (2006). Carotenoid and vitamin content of Karat and other Micronesian banana cultivars. International Journal of Food Science and Nutrition, 57(5-60), 399-418. https://doi.org/10.1080/09637480600872010

Fernandes, E.G., Leal, P.A.M. and Sanches, J. (2010). Climatização e armazenamento refrigerado na qualidade pós-colheita de bananas 'nanicão'. Bragantia, 69(3), 735-744. https:// doi.org/10.1590/S0006-87052010000300027

Fikselová, M., Šilhár, S., Mareček, J. and Frančáková, H. (2008). Extraction of carrot (Daucus carota L.) carotenes under different conditions. Czech Journal of Food Sciences, 26(4), 268-274. https:// doi.org/10.17221/9/2008-CJFS

Harvard Health Publishing (2020). Glycemic index for $60+$ foods. Retreived from Harvard Health website: https://www.health.harvard.edu/diseases-andconditions/glycemic-index-and-glycemic-load-for100 -foods

Gomes, F.P. and Prado, C.H. (2007). Ecophysiology of coconut palm under water stress. Brazilian Journal of Plant Physiology, 19(4), 377-391. https:// doi.org/10.1590/S1677-04202007000400008

Gross, J. (1987). Pigments in fruit (No. 04; QK898, G7.). London, United Kingdom: Academic Press.

Hettiaratchi, U.P.K., Ekanayake, S. and Welihinda, J. (2011). Chemical compositions and glycemic responses to banana varieties. International Journal of Food Sciences and Nutrition, 62(4), 307-309. https://doi.org/10.3109/09637486.2010.537254

Konopacka, D. and Plocharski, W.J. (2004). Effect of storage conditions on the relationship between apple firmness and texture acceptability. Postharvest Biology and Technology, 32(2), 205-211. https:// doi.org/10.1016/j.postharvbio.2003.11.012

Lee, S.K. and Kader, A.A. (2000). Preharvest and postharvest factors influencing vitamin $\mathrm{C}$ content of horticultural crops. Postharvest Biology and Technology, 20(3), 207-220. https://doi.org/10.1016/ S0925-5214(00)00133-2

Lichtemberg, L.A. and Lichtemberg, P.D.S.F. (2011). Avanços na bananicultura brasileira. Revista Brasileira de Fruticultura, 33(SPE1), 29-36. [In 
Portugese]. 29452011000500005

Lima, O.S., Souza, E.G., Amorim, E.P. and Pereira, M.E.C. (2014). Ripening and shelf life of 'BRSCaipira' banana fruit stored under room temperature or refrigeration. Ciência Rural, 44(4), 734-739. 84782014000400027

Martins, R.N., Dias, M.S.C., Vilas Boas, E.V.D.B. and Santos, L.O. (2007). Armazenamento refrigerado de banana 'PrataAnã' proveniente de cachos com 16, 18 e 20 semanas. Ciência e Agrotecnologia, 31(5), 1423 -1429. [In Portugese]. https://doi.org/10.1590/S141370542007000500023

Matsuura, F.C.A.U., Costa, J.I.P.D. and Folegatti, M.I.D.S. (2004). Marketing de banana: preferências do consumidor quanto aos atributos de qualidade dos frutos. Revista Brasileira de Fruticultura, 26(1), 4852. https://doi.org/10.1590/S0100-

\section{4}

McCseady, R.M. (1971). Determination of starch and dextrin in methods of Food Analysis, $2^{\text {nd }}$ ed. A series of monographs, D.225-227. London, United Kingdom: Academic Press.

Newilah, G.N., Dhuique-Mayer, C., Rojas-Gonzalez, J., Tomekpe, K., Fokou, E. and Etoa, F.X. (2009). Carotenoid contents during ripening of banana hybrids and cultivars grown in Cameroon. Fruits, 64 (4), 197-206. https://doi.org/10.1051/fruits/2009015

Olsson, M.E., Andersson, C.S., Oredsson, S., Berglund, R.H. and Gustavsson, K.E. (2006). Antioxidant levels and inhibition of cancer cell proliferation in vitro by extracts from organically and conventionally cultivated strawberries. Journal of Agricultural and Food Chemistry, 54(4), 1248-1255. https:// doi.org/10.1021/jf0524776

Patil, S.K. and Shanmugasundaram, S. (2015). Physicochemical changes during ripening of Monthan banana. International Journal of Technology Enhancements and Emerging Engineering Research, 3(2), 2347-4289.

Puwastien, P., Raroengwichit, M., Sungpuag, P.andJudprasong, K. (1999). Thai food composition tables. Salaya, Thailand: Institute of Nutrition, Mahidol University.

Segundo, C., Román, L., Lobo, M., Martinez, M.M. and Gómez, M. (2017). Ripe banana flour as a source of antioxidants in layer and sponge cakes. Plant Foods for Human Nutrition, 72(4), 365-371. https:// doi.org/10.1007/s11130-017-0630-5

Shiga, T.M., Soares, C.A., Nascimento, J.R., Purgatto, E., Lajolo, F.M. and Cordenunsi, B.R. (2011). Ripening-associated changes in the amounts of starch and non-starch polysaccharides and their contributions to fruit softening in three banana cultivars. Journal of the Science of Food and Agriculture, 91(8), 1511-1516. https:// doi.org/10.1002/jsfa.4342

Soares, C.A., Peroni-Okita, F.H.G., Cardoso, M.B., Shitakubo, R., Lajolo, F.M. and Cordenunsi, B.R. (2011). Plantain and banana starches: granule structural characteristics explain the differences in their starch degradation patterns. Journal of Agricultural and Food Chemistry, 59(12), 66726681. https://doi.org/10.1021/jf201590h

Siong, T.E. (1985). Nutrient composition of Malaysian Foods - a preliminary table (first up-date). Kuala Lumpur: Division of Human Nutrition, Institute for Medical Research and Asean Protein Project, National Sub-committee Malaysia.

Someya, S., Yoshiki, Y. and Okubo, K. (2002). Antioxidant compounds from bananas (Musa Cavendish). Food chemistry, 79(3), 351-354. https:// doi.org/10.1016/S0308-8146(02)00186-3

Sousa, C.M.D.M., Silva, H.R., Ayres, M.C.C., Costa, C.L.S.D., Araújo, D.S., Cavalcante, L.C.D. and Chaves, M.H. (2007). Fenóistotais e atividadeantioxidante de cincoplantasmedicinais. Química nova, 30(2), 351$355 . \quad$ https://doi.org/10.1590/S010040422007000200021

Thompson, J.J and Manore, M. (2017). Nutrition: An applied approach. $5^{\text {th }}$ ed. New York: Pearson.

Tran, B.L, Ton, N.M.N and Dinh, T.N.T. (2004). Food Biochemical Experiment, p. 83. Ho Chi Minh, Viet Nam: Ho Chi Minh City National University Publishing.

Valmayor, R.V., Jamaluddin, S.H., Silayoi, B., Danh, L.D., Pascua, O.C. and Espino, R.R.C. (2002). Banana Cultivar Names And Synonyms In Southeast Asia. International Network for the Improvement of Banana and Plantain-Asia and the Pacific. France: INIBAP.

Von Loesecke, H.W. (1950). Bananas, chemistry, physiology, technology. $2^{\text {nd }}$ ed. USA: Interscience Publishers, Inc

Yang, X., Song, J., Fillmore, S., Pang, X. and Zhang, Z. (2011). Effect of high temperature on color, chlorophyll fluorescence and volatile biosynthesis in green-ripe banana fruit. Postharvest Biology and Technology, 62(3), 246-257. https://doi.org/10.1016/ j.postharvbio.2011.06.011 